\title{
Cigarette Smoke Modulates NOD1 Signal Pathway and Human $\beta$ Defensins Expression in Human Oral Mucosa
}

\author{
Ya-jie Qian ${ }^{a}$ Xiang Wang ${ }^{a, d, e}$ Ya-fan Gao ${ }^{a}$ Ning Duan ${ }^{a}$ Xiao-feng Huang ${ }^{b}$ \\ Fang-fang Sunc,d,e Xiao-dong Han ${ }^{\mathrm{d}, e}$ Wen-mei Wang ${ }^{\mathrm{a}}$
}

aDepartment of Oral Medicine, bepartment of Oral Pathology, and 'Department of Prosthodontics, Nanjing Stomatological Hospital, Medical School of Nanjing University, Nanjing, China, ${ }^{d}$ Immunology and Reproduction Biology Laboratory, Jiangsu Key Laboratory of Molecular Medicine, Medical School, Nanjing University, and 'State Key Laboratory of Analytical Chemistry for Life Science, Nanjing University, Nanjing, China

\section{Key Words}

Cigarette smoke $\bullet$ NOD1 signal pathway $\bullet$ Human $\beta$ defensins $\bullet$ Oral mucosa

\begin{abstract}
Background/Aims: Nucleotide binding oligomerization domain 1 (NOD1) signal pathway and human $\beta$ defensins (hBDs) play crucial roles in innate immune. Cigarette smoke has been confirmed to dampen innate immune in some human tissues, such as oral mucosa. The aim of this study was to evaluate potential effects of smoking on NOD1 signaling and hBDs expression in oral mucosa. Methods: Tissue specimens of normal oral mucosa were collected from donors undergoing routine surgical treatment. All 20 participants were classified equally as two groups: non-smokers and smokers. By using Western blotting and immunohistochemistry, we investigated differential expression of crucial molecules in NOD1 signal pathway, hBD-1, -2 , and -3 in oral mucosa tissues between non-smokers and smokers. Immortalized human oral mucosal epithelial (Leuk-1) cells were treated with various concentrations of cigarette smoke extract (CSE) for $24 \mathrm{~h}$. Western blotting and immunofluorescence assays were performed to study CSE-induced alteration of protein expression. Leuk-1 cells were treated with $4 \% \mathrm{CSE}$, iE-DAP (NOD1 agonist), CSE + iE-DAP, BAY 11-7082 (NF-kB inhibitor), 4\% CSE + BAY 117082, respectively. Real-time PCR and ELISA were performed to detect the mRNA levels and secretion of hBD-1, -2 , and -3 , respectively. Results: The levels of NOD1, NF-KB, hBD-1 and hBD-3 significantly reduced in oral mucosa tissues of smokers compared with non-smokers. The levels of RIP2 (receptor-interacting protein 2), phospho-NF-KB (P-NF-KB) and hBD-2 remarkably enhanced in oral mucosal tissues of smokers. CSE treatment suppressed NOD1 and NF-KB expression and activated RIP2 and P-NF-KB expression in Leuk-1 cells. The mRNA Y.-j. Qian and X. Wang contribute equally to this work

Professor Wen-mei Wang And Professor Xiao-dong Han

KARGER 125

Dept Oral Medicine, Nanjing Stomatological Hospital, Medical School of Nanjing University, 30 Zhongyang Road, Nanjing 210008, (China) and Immunol Reprod Biology Lab, Jiangsu Key Laboratory of Molecular Medicine, Medical School, Nanjing University, 22 Hankou Road, Nanjing 210093, (China)

E-Mail wenmei-wang@hotmail.com, E-Mail hanxd@nju.edu.cn
\end{abstract}




\section{Cellular Physiology Cell Physiol Biochem 2015;36:457-473 \\ \begin{tabular}{l|l} 
DOI: 10.1159/000430112 & (C) 2015 S. Karger AG, Basel
\end{tabular} \\ \begin{tabular}{l|l} 
and Biochemistry Published online: May 11, 2015 & www.karger.com/cpb
\end{tabular} \\ Qian et al.: Smoking Modulates NOD1 Signaling}

and secretory levels of hBD-1 and -3 were down-regulated by CSE, while the mRNA and secretory level of hBD-2 were up-regulated by CSE. The iE-DAP or BAY 11-7082 treatment reversed the regulatory effects of CSE on levels of hBDs. Conclusion: The present study indicated that cigarette smoke could potentially modulate the expression of crucial molecules of NOD1 signal pathway and hBDs in human oral mucosal epithelium. NOD1 signal pathway could play an important role in the regulatory effects of CSE on hBDs levels in oral mucosal epithelial cells.

Copyright $@ 2015$ S. Karger AG, Basel

\section{Introduction}

Cigarette smoke increases the susceptibility to oral mucosal infection and is a risk factor for malignant transformation. Smoking is a well recognized risk for periodontitis, oral candidiasis, oral leukoplakia and oral cancer $[1,2]$. The epithelium of oral mucosa acts as a defense shield against microorganisms and other harmful stimulating factors such as smoking.

Innate immune system is responsible for initial host defense against invasive pathogens, where pathogen-associated molecular patterns (PAMPs) are dependent on pattern recognition receptors (PRR). Representative human PRRs are Toll-like receptors (TLRs) and intracellular nucleotide binding oligomerization domain (NOD)-like receptors (NLRs). Previous studies have confirmed that NOD1 and NOD2 are clearly expressed in oral epithelium. NOD1 seems to be more ubiquitously and constitutively expressed in epithelial cell lines than NOD2 [3]. NOD1 is a fundamental member of NLR family and NOD1 signal pathway plays a crucial part in innate immune of oral mucosal epithelium [3-5]. The oligomerization of NOD proteins following peptidoglycan recognition results in the recruitment of RIP2 (receptor interacting protein 2), which in turn interacts with the IKK [I $\mathrm{KB}$ (inhibitor of NF- $\kappa \mathrm{B}$ ) kinase] complex and activates NF- $\kappa B$ signaling $[6,7]$. NF- $\kappa B$ activation promotes the production of proinflammatory cytokines, chemokines, and antimicrobial peptides, such as human $\beta$ defensin (hBD) [8]. The hBD family is one type of cationic antimicrobial peptides that can be secreted by epithelial cells. Among hBD family, hBD-1, -2 and -3 are critical members of the defense system of oral mucosal epithelium [9].

Previous studies have determined that cigarette smoke affects the expression of TLRs $[10,11]$. However, effects of cigarette smoke on NLRs have not been understood well. An early study showed that cigarette smoke extract (CSE) delayed NOD2 expression and affected NOD2/RIP2 interactions in intestinal epithelial cells [12]. The impacts of smoking on hBDs expression in human gingival tissues or cells have been investigated in previous studies. Wolgin et al. found that the expression of hBD-1 and -2 mRNA was significantly reduced in gingival samples of smokers compared with non-smokers [13]. The study results of Semlali et al. suggested that whole cigarette smoke exposure up-regulated mRNA levels and release of hBD-2 and hBD-3 by human gingival epithelial cells [10]. Another study from Mahanonda et al. showed that CSE modulated hBD-2 mRNA in human gingival epithelial cells [11]. Clarifying effects of smoking on NOD1 signal pathway and hBDs expression will improve the knowledge on the relationship between cigarette smoke and oral mucosal diseases. Therefore, the aim of the present study was to compare the expression levels of NOD1, RIP2, NF- $\kappa B$, phospho-NF- $\kappa B$ (P-NF- $\kappa B$ ), hBD-1, -2 , and -3 in normal oral mucosa tissues between smokers and non-smokers. To better explore impacts of cigarette smoke exposure, we evaluated the differential expression of NOD1 and other molecules in the immortalized human oral mucosal epithelial cell line (Leuk-1) between cigarette smoke extract (CSE) treatment and control groups. 


\section{Cellular Physiology Cell Physiol Biochem 2015;36:457-473 \begin{tabular}{l|l|l}
\hline DOI: 10.1159/000430112 & C 2015 S. Karger AG, Basel
\end{tabular} \begin{tabular}{l|l} 
and Biochemistry Published online: May 11, 2015 & www.karger.com/cpb \\
\cline { 1 - 2 }
\end{tabular}

\section{Materials and Methods}

\section{Patients}

The study was approved by the Ethics Committee of Institute and Hospital of Stomatology, Nanjing University Medical School (IRB Approval Number: NK2011-03). Normal specimens of oral mucosa were excised from patients who received orthognathic surgery or surgical removal of completely impacted third molar. All 20 participants had received printed information and signed a written consent according to the guideline and regulation of the Ethics Committee. The patients were interviewed about smoking habits, and were equally classified into two groups: smokers $(n=10)$ and non-smokers $(n=10)$. All smokers were cigarette smokers, and those who reported the use of $\geq 10$ cigarettes per day (range $10 \sim 40$ cigarettes per day) were classified as smokers. Patients classified as non-smokers had no history of tobacco smoking at all. For ethical reasons, smokers were informed about the potentially negative effects of smoking on health, and were encouraged to cease smoking. Pregnant and lactating women, patients with systemic diseases, patients who had taken any medication in the past $24 \mathrm{~h}$ before treatment, and patients with untreated periodontal diseases as well as occasional smokers were excluded from the study [13]. The patients with periodontal diseases received periodically the periodental non-surgical treatment, including supragingival, subgingival scaling or root planning, etc. As for smokers, tissue sampling was finished $24 \mathrm{~h}$ after the last cigarette was smoked. Among all the patients, no obvious inflammatory appearance was clinically observed in the area of surgery. Some tissue specimens of oral mucosa were immediately frozen in liquid nitrogen and stored at $-80^{\circ} \mathrm{C}$ for Western blotting assay. Other tissue specimens of oral mucosa were immediately formalin-fixed for immunohistochemistry study.

\section{Reagents}

Phosphatase inhibitor cocktail was purchased from Roche (Mannheim, Germany). Protease inhibitor cocktail was purchased from Fermentas UAB (Vilnius, Lithuania). Protein assay reagent and an enhanced chemiluminescent (ECL) kit were purchased from Pierce (Rockford, IL, USA). The following primary antibodies were used: rabbit anti-NOD1 antibody (ab97278), mouse anti-RIP2 antibody (ab57954), rabbit anti-NF- $\kappa B$ (p65 subunit) antibody (ab137692), rabbit anti-P-NF- $\kappa B$ (Phospho-p65 subunit) antibody (ab109458), rabbit anti-P-NF- $\kappa$ B (Phospho-p65 subunit) antibody (ab135551), mouse anti-hBD-1 antibody (ab14425), and rabbit anti-hBD-2 antibody (ab63982) were purchased from Abcam (Cambridge, UK); rabbit anti-hBD-3 antibody (NB200-117) was purchased from Novus (Littleton, CO, USA); mouse anti-NFкB (p65 subunit) antibody (\#6956) and rabbit anti-GAPDH antibody (\#2118) were purchased from Cell Signaling (Danvers, MA, USA). The primary antibodies against NOD1 (ab97278) and RIP2 (ab57954) were used for Western blotting, immunohistochemistry and immunofluorescence, while the primary antibodies to hBD-1 (ab14425), hBD-2 (ab63982), and hBD-3 (NB200-117) were used for immunohistochemistry and immunofluorescence. The mouse anti-NF- $\kappa B$ (\#6956) primary antibody was used for Western blotting and immunohistochemistry, while the rabbit anti-NF- $\mathrm{KB}$ (ab137692) primary antibody was used for immunofluorescence. The rabbit anti-P-NF- $\kappa B$ (ab109458) primary antibody was used for Western blotting, while the rabbit anti-P-NF- $\mathrm{KB}$ (ab135551) primary antibody was used for immunohistochemistry and immunofluorescence. The rabbit anti-GAPDH primary antibody (\#2118) was used for Western blotting. Keratinocyte Serum-Free Medium (K-SFM) for culture of human keratinocytes was purchased from GIBCO (Invitrogen, Carlsbad, CA, USA). 5-diphenyltetrazolium bromide (MTT), NF-кB inhibitor BAY 11-7082, Dimethyl Sulfoxide (DMSO) and 4', 6-diamidino-2-phenylindole (DAPI) were purchased from Sigma (St. Louis, MO, USA). NOD1 agonist iE-DAP ( $\gamma$-D-glutamyl-meso-diaminopimelic acid) and negative control iELys ( $\gamma$-D-glutamyl-Lysine) were purchased from InvivoGen (San Diego, CA, USA). Alexa Fluor 555-labeled goat-anti-rabbit secondary antibody and Dylight Fluor 488-labeled goat-anti-mouse secondary antibody were purchased from Jackson ImmunoResearch (West Grove, PA, USA). TRIzol reagent using for total RNA extract was purchased from Invitrogen (Carlsbad, CA, USA). RevertAid First Strand cDNA synthesis kit was purchased from Thermo Fisher Scientific (Waltham, MA, USA), and SYBR Green PCR Master Mix was purchased from Roche (Mannheim, Germany). ELISA kits for the measurement of hBDs secretion were purchased from R\&D Systems (Minneapolis, MN, USA).

Immunohistochemistry

Formalin-fixed and paraffin-embedded specimens were cut into 4 - $\mu$ m-thick sections, which were subsequently deparaffinized and hydrated. Briefly, tissue sections were stained using specific primary 


\section{Cellular Physiology Cell Physiol Biochem 2015;36:457-473 \\ \begin{tabular}{l|l|l} 
DOI: 10.1159/000430112 & C 2015 S. Karger AG, Basel
\end{tabular} \begin{tabular}{l|l} 
and Biochemistry Published online: May 11, 2015 & www.karger.com/cpb \\
\cline { 1 - 2 }
\end{tabular} \\ Qian et al.: Smoking Modulates NOD1 Signaling}

antibodies, biotin-conjugated secondary antibodies, and horse radish peroxidase (HRP)-conjugated avidin. Specific antibody interactions were detected with the HRP substrate 3, 3'-diaminobenzidine (DAB). Subsequently, sections were washed and counterstained with hematoxylin. For the negative control, phosphate-buffered saline was used in place of the primary antibodies. Appropriate positive controls were concurrently performed. Primary antibodies against the following proteins were used: NOD1 (1:200

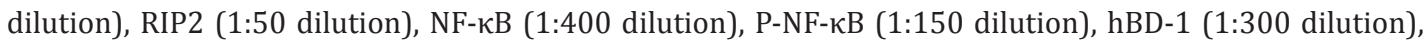
hBD-2 (1:500 dilution), and hBD-3 (1:400 dilution). Densitometry image analysis was performed as previously reported $[14,15]$ with some modifications. Briefly, immunohistochemical images were acquired using a Leica microscope coupled to a Leica DC500 digital camera (Leica, Wetzlar, Germany). Photographs were taken using identical conditions for light setting and contrast. Ten randomly selected discontinuous fields (400x) per slice were evaluated. The densitometry analysis of immunohistochemical results was performed by one blinded investigator using Image Pro Plus analysis software (version 6.0; Dallas, TX, USA). The calibration procedure was finished before image analysis. The color segmentation algorithm was then used to separate the contribution of the DAB and hematoxylin dyes. The mean value of the optical densities of all selected pixels was Mean Optical Density (MOD).

\section{Western blotting}

Western blotting was performed as described.[16] Tissues or Cells were lysed in ice-cold lysis buffer containing protease inhibitor and phosphatase inhibitor cocktail. $10 \mathrm{ml}$ complete protease inhibitor cocktail was added per $1 \mathrm{mg}$ sample. To homogenise the sample, $10 \mathrm{ml} 100 \mathrm{mM} \mathrm{1,4-dithiothreit} \mathrm{(DTT)} \mathrm{were} \mathrm{added}$ per $100 \mathrm{mg}$ of sample. The lysates were incubated on ice for $30 \mathrm{~min}$ and centrifuged at $14,000 \mathrm{~g}$, for 10 min, at $4{ }^{\circ} \mathrm{C}$, to remove cell debris. The Western blotting was performed under the denaturing conditions. Total cellular protein was collected, denatured and separated by $10 \%$ gradient gel and electrophoretically transferred to polyvinylidene difluoride membranes. After blocking for $1 \mathrm{~h}$ at room temperature, blots were incubated respectively with primary antibody specific for NOD1, RIP2, NF- $\kappa$ B, P-NF- $\kappa$ B and GAPDH overnight at $4^{\circ} \mathrm{C}$ and followed by each corresponding second antibody at room temperature for $1 \mathrm{~h}$ at $37^{\circ} \mathrm{C}$. Then, the results were developed by ECL kits. Densitometric analyses of immunoblot bands were performed using Image J software and the data of target protein were normalized to those of corresponding GAPDH (http://rsb.info.nih.gov/ij/). Normalized data were represented as percentage or fold change compared with corresponding control, which was set to 1 or 100.

\section{Cell line and cell culture}

Immortalized human oral mucosal epithelial (Leuk-1) cell line was a generous gift from Professor Li Mao at Department of Oncology and Diagnostic Sciences, University of Maryland Dental School, Baltimore, MD. The cell line was expanded and passaged in keratinocyte serum free medium. This medium was supplemented with BPE $(25 \mu \mathrm{g} / \mathrm{ml})$, epidermal growth factor $(0.2 \mathrm{ng} / \mathrm{ml}), \mathrm{CaCl}_{2}(0.4 \mathrm{mM})$. The passaged cells were cultured in $37^{\circ} \mathrm{C}$ humidified air incubators with $5 \% \mathrm{CO}_{2}$. Cells were routinely grown to $70 \%$ confluency, and trypsinized with $0.25 \%$ trypsin/0.02 EDTA solution.

\section{Cigarette smoke extract (CSE) preparation}

Kentucky 3R4F research-reference filtered cigarettes used for CSE preparation were purchased from the Tobacco Research Institute, University of Kentucky (Lexington, KY, USA). CSE was prepared by a peristaltic pump as previously described $[17,18]$. The smoke of one 3R4F reference cigarette was bubbled through $10 \mathrm{ml}$ of keratinocyte serum free medium at a speed of $50 \mathrm{ml} / \mathrm{min}$. The resulting solution was filtered through a $0.22-\mu \mathrm{m}$ pore filter to remove bacteria and large particles. The CSE solution was adjusted to a pH of 7.45 and used within 15 min after preparation. This solution, considered to be $100 \%$ CSE, was diluted and applied to cell cultures within $30 \mathrm{~min}$ of preparation.

\section{Measurement of cell Viability}

Cell viability was measured by conventional MTT assay as previously described [19]. Leuk-1 cells were cultured in 96-well plates at a density of $1 \times 10^{5}$ cells $/ \mathrm{ml}$ and then were treated with different concentrations of $\operatorname{CSE}(0,1 \%, 2 \%, 4 \%, 8 \%, 16 \%, 32 \%, 64 \%$ and $90 \%)$, with different concentrations of NOD1 agonist iEDAP $(0,0.1 \mu \mathrm{g} / \mathrm{ml}, 1 \mu \mathrm{g} / \mathrm{ml}, 10 \mu \mathrm{g} / \mathrm{ml}, 50 \mu \mathrm{g} / \mathrm{ml}, 100 \mu \mathrm{g} / \mathrm{ml}, 1000 \mu \mathrm{g} / \mathrm{ml})$, or with different concentrations of NF- $\kappa$ B inhibitor NF BAY 11-7082 $(0,1 \mu \mathrm{M}, 5 \mu \mathrm{M}, 10 \mu \mathrm{M}, 20 \mu \mathrm{M}, 50 \mu \mathrm{M}, 100 \mu \mathrm{M}, 200 \mu \mathrm{M}$, and $400 \mu \mathrm{M})$ for $24 \mathrm{~h}$ 


\section{Cellular Physiology Cell Physiol Biochem 2015;36:457-473 \\ \begin{tabular}{l|l} 
DOI: 10.1159/000430112 & (C) 2015 S. Karger AG, Basel
\end{tabular} \\ \begin{tabular}{l|l} 
and Biochemistry Published online: May 11, 2015 & www.karger.com/cpb \\
\cline { 1 - 2 }
\end{tabular} \\ Qian et al.: Smoking Modulates NOD1 Signaling}

at $37^{\circ} \mathrm{C}$ and $5 \% \mathrm{CO}_{2}$ atmosphere. Ten microlitres of MTT solution ( $5 \mathrm{mg} / \mathrm{ml}$ in phosphate buffered-saline) was added to each well. After $4 \mathrm{~h}$ incubation, the supernatant was discarded, 150 microlitres of DMSO was added and the plate was shaken to dissolve the formazan. Absorbance was determined by using a multiplate reader (Bio-Rad 680, Hercules, CA, USA) at a wavelength of $570 \mathrm{~nm}$.

\section{Immunofluorescence}

Leuk1 cells were grown on glass coverslips and stimulated with 4\% concentration of CSE or fresh medium (control) for $24 \mathrm{~h}$. Next, Leuk-1 cells were washed with PBS and fixed in 4\% paraformaldehyde for 15 min at room temperature. After being washed in PBS, the cells were permeabilized in $0.5 \%(\mathrm{v} / \mathrm{v}$ ) Triton $\mathrm{X}-100$ in PBS, washed, and blocked with 5\% BSA in PBS- $0.1 \%$ Tween 20 for $1 \mathrm{~h}$ at $37^{\circ} \mathrm{C}$. Next, the cells were exposed overnight at $4^{\circ} \mathrm{C}$ to primary antibodies. Primary antibodies against the following proteins were

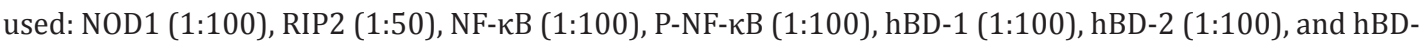
3 (1:100). The next day, coverslips were washed with PBS and then incubated with Dylight 488 (green) or Alexa Fluor 555 (red) - labeled secondary antibody for $1 \mathrm{~h}$ at room temperature. To stain the nuclei, DAPI was added for $5 \mathrm{~min}$, and slides were examined by a confocal laser scanning microscope (FluoView FV10i, Olympus, Japan).

\section{iE-DAP treatment}

The peptidoglycan-like molecule iE-DAP and the negative control compound iE-Lys (all with endotoxin levels $<0.125 \mathrm{EU} / \mathrm{ml}$ ) were obtained from InvivoGen. Treatment of Leuk-1 cells with iE-DAP (NOD1 specific agonist) was performed as previously described [20,21]. Leuk-1 cells (prepared as detailed above) were pretreated for $24 \mathrm{~h}$ with the presence of $50 \mu \mathrm{g} / \mathrm{ml} \mathrm{iE-DAP} \mathrm{or} 50 \mu \mathrm{g} / \mathrm{ml} \mathrm{iE}$-Lys. Leuk-1 cells were then either untreated (control) or treated with $4 \%$ CSE for $24 \mathrm{~h}$.

\section{BAY 11-7082 treatment}

Available researches and our preliminary experiment showed NF- $\kappa$ B specific inhibitor BAY 11-7082 in low-does could inhibit NF- $\kappa$ B activity without inducing significant cell apoptosis. Treatment of Leuk-1 cells with BAY 11-7082 was performed as previously described [22, 23]. Briefly, Leuk-1 cells were pretreated with $10 \mu \mathrm{M}$ BAY 11-7082 for $24 \mathrm{~h}$. Then cells were treated with 4\% CSE for $24 \mathrm{~h}$. Leuk-1 cells were treated with $0.5 \%$ DMSO as a mock-treated control.

\section{Quantitative RT-PCR}

Total RNA from Leuk-1 cells was extracted using a modified TRIzol protocol and spectrophometrically quantitated. Equal amounts $(2 \mu \mathrm{g})$ of RNA for each sample were used with oligo (dT) as primers for the production of cDNA (SuperScript II First-Strand Synthesis System for RT-PCR, Roche) to produce cDNA. Real-time PCR analyses ware performed using an ABI 7300 Real Time PCR System (Applied Biosystem, Foster City, CA), and PCR amplifications were performed using the SYBR Green PCR Master Mix according to the manufacturer's instructions. Gene-specific primers for hBD-1, -2, -3 and GAPDH housekeeping genes were used in standard PCR with the following program: $50^{\circ} \mathrm{C}$ for $2 \mathrm{~min}, 95^{\circ} \mathrm{C}$ for $10 \mathrm{~min}, 40 \mathrm{cycles}$ of $95^{\circ} \mathrm{C} \mathrm{for}$ $15 \mathrm{~s}, 58^{\circ} \mathrm{C}$ for $30 \mathrm{~s}$, and $72^{\circ} \mathrm{C}$ for $30 \mathrm{~s}$, followed by melting curve analysis, by which the specificity of primers was confirmed. The experiment was repeated three times. The data are expressed as relative mRNA levels and were normalized to GAPDH. Fold changes in expression of each gene were calculated by a comparative threshold cycle $(\mathrm{Ct})$ method using the formula $2^{-(\Delta \Delta \mathrm{Ct})}$. The qPCR primers used for measuring mRNA levels of hBDs crossed exons. Primer sequences were as follow: hBD-1 forward TCA TTA CAA TTG CGT CAG CAG, reverse TTG CAG CAC TTG GCC TTC [13]; hBD-2 forward TCC TCT TCT CGT TCC TCT TCA, reverse AGG GCA AAA GAC TGG ATG AC [13]; hBD-3 forward CCA TTA TCT TCT GTT TGC TTT GCT C, reverse CCG CCT CTG ACT CTG CAA TAA TA [24]; GAPDH forward GCA CCG TCA AGG CTG AGA AC, reverse TGG TGA AGA CGC CAG TGG A [25].

\section{Enzyme-linked immunosorbent assay (ELISA)}

To detect the amount of hBD-1, -2 , and -3 produced by Leuk-1 cells, cell culture supernatant was quantified using an enzyme-linked immunosorbant assay (R \& D Systems) according to the manufacturer's instructions. hBD-1, $-2,-3$ standard was used to construct standard curves. The supplied primary antibody and strepavidin-HRP secondary antibody were added. After incubation with the provided substrate 
Table 1. The demographic parameters of study participants. SD: standard deviation

\begin{tabular}{cccccc}
\hline \multirow{2}{*}{ Smoking } & \multicolumn{2}{c}{ Gender } & \multicolumn{3}{c}{ Age(years) } \\
& & Men & Women & Mean & SD \\
\hline Non-smokers & 10 & 4 & 6 & 32.8 & 11.7 \\
Smokers & 10 & 7 & 3 & 36.6 & 13.3 \\
\hline
\end{tabular}

Fig. 1. Protein expression levels of NOD1, RIP2, NF- $\kappa$ B and $\mathrm{P}-\mathrm{NF}-\mathrm{KB}$ in normal oral mucosal tissues were differential between non-smokers and smokers. Representative immunoblot bands of NOD1, RIP2, NF- $\kappa B$ and P-NF- $\kappa B(A)$. Density analyses of immunoblot bands indicated significantly decreased NOD1 level (B), increased RIP2 level (C), reduced NF- $\kappa B$ level (D), augmented P-NF- $\kappa$ B level (E) and enhanced the ratio of $\mathrm{P}-\mathrm{NF}-\kappa \mathrm{B}$ to total NF- $\kappa \mathrm{B}(\mathrm{F})$ in oral mucosal tissues of smokers compared with that of non-smokers. Density data of bands were represented as means $\pm \mathrm{SE}$ (n $=8$ /group). Statistical significance: ${ }^{*} P<0.05,{ }^{* *} P<0.01$ Smokers vs. Non-smokers.

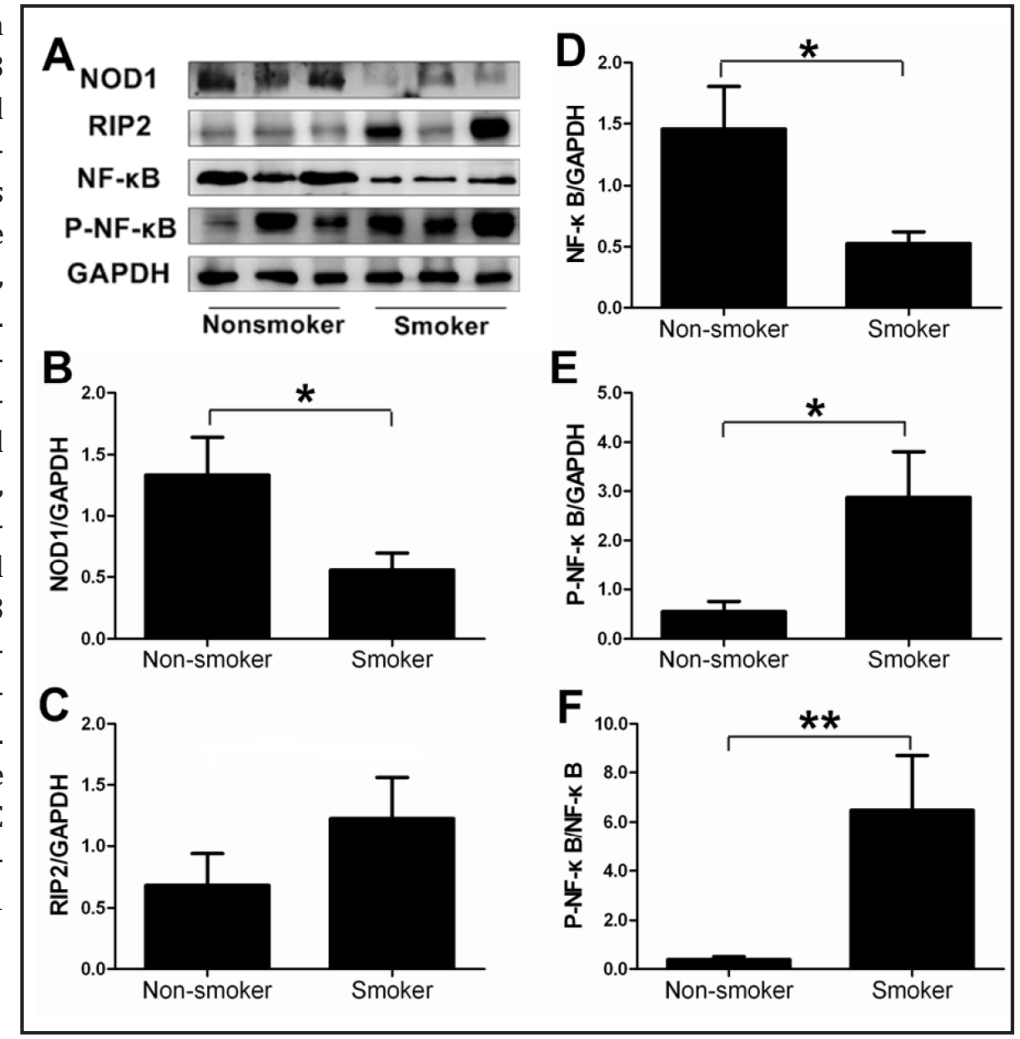

solution, the reaction was stopped with the addition of stop solution, and the plate was read at $450 \mathrm{~nm}$ using a spectrophotometric plate reader.

\section{Statistical analyses}

Statistical analyses were performed using SPSS 15.0 (Chicago, IL). Data represented as mean \pm SEM. To determine whether parameters were normally distributed, the Kolmogorov-Smirnov statistic test was applied. Normally distributed data were analyzed using the unpaired $t$-test for differences between groups whereas non-normally distributed ones were analyzed with Mann Whitney test. $P$ values $<0.05$ were considered statistically significant.

\section{Results}

NOD1, RIP2, NF- $\kappa B$ and P-NF- $\kappa B$ levels were altered in oral mucosa of smokers

In the present study the expression levels of crucial molecules in NOD1 signaling pathway were analyzed. The study participants included 20 patients, 11 men and 9 women, with an age range from 19 to 56 years (median 34.7 years; Table 1). The average number of cigarettes smoked among smokers group was 19.40 pack years (standard deviation: 20.18 pack years). Western blotting and immunohistochemistry assays were used to examine the expression of NOD1, RIP2, NF- $\kappa B$ and P-NF- $\kappa B$ in normal oral mucosa tissues of healthy smokers and non-smokers. Representative immunoblot bands were presented in Figure 1. As shown by Western blotting results, the protein levels of NOD1 and NF- $\kappa B$ in the smoker group were significantly lower than that of the non-smoker group. Compared with that in 


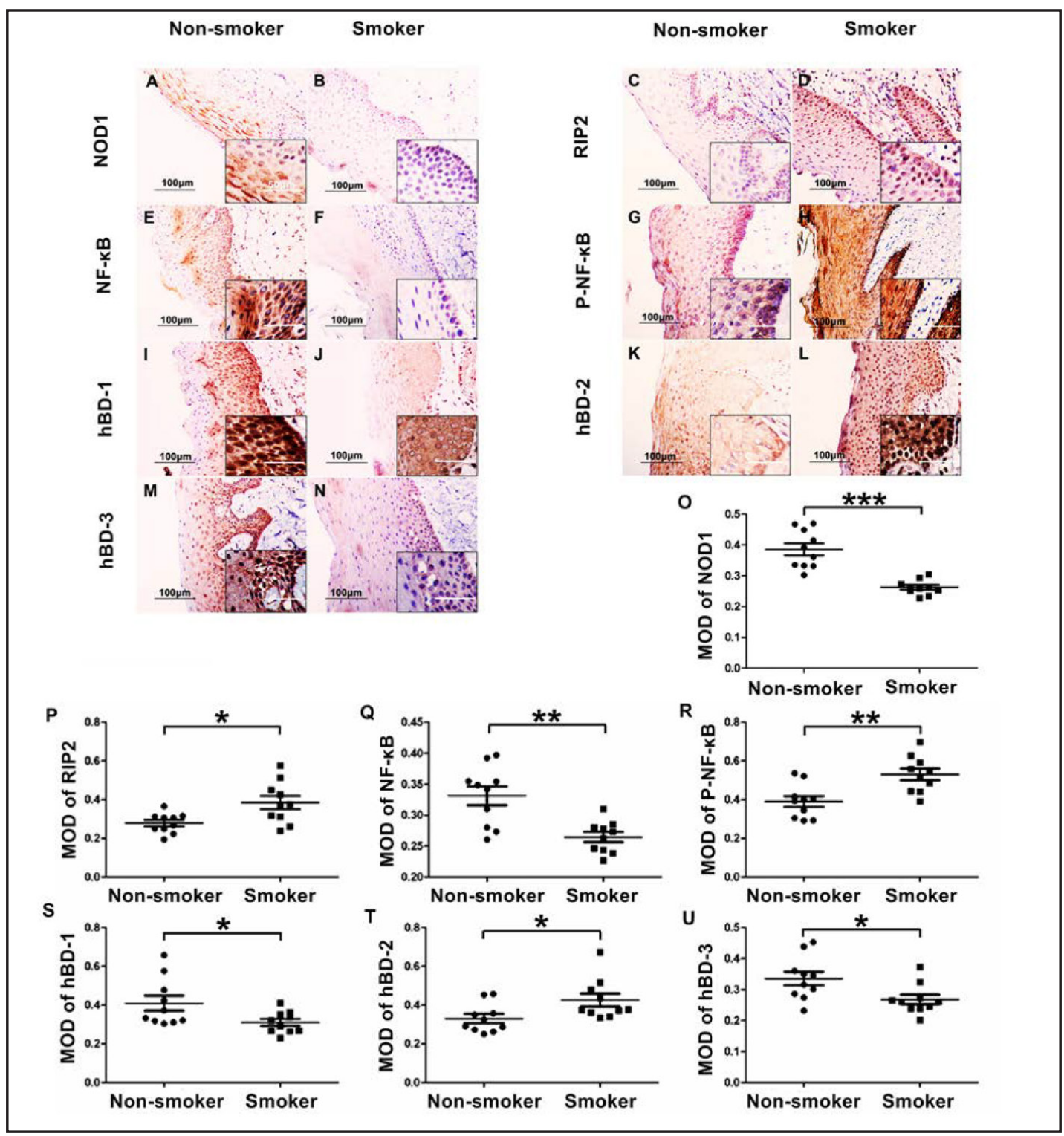

Fig. 2. Expression of crucial molecules in NOD1 signal pathway and hBDs was remarkably altered in oral mucosal epithelium of smokers. Representative immunohistochemical stainings of crucial molecules in NOD1 signal pathway, hBD-1, -2 and -3 in oral mucosal epithelium of non-smokers (A, C, E, G, I, K, M) and smokers (B, D, F, H, J, L, N). In high power magnification, scale bar = $50 \mu \mathrm{m}$ (insets). Digital image analysis of immunohistochemical results indicated that expression levels of NOD1, NF- $\kappa B$, hBD-1 and hBD-3 in oral mucosal epithelium of smokers were significantly reduced than that of non-smokers $(0, Q, S, U)$, while expression levels of RIP2, P-NF- $\mathrm{B}$, and hBD-2 in oral mucosal epithelium of smokers were markedly increased than that of non-smokers (P, R, T). The level of protein expression was quantified by measuring the mean optical density (MOD) of immunohistochemical stainings. MOD was represented as means \pm SE $(n=10 /$ group). Statistical significance: ${ }^{*} P<0.05,{ }^{* *} P<0.01,{ }^{* * *} P<0.001$, Smokers vs. Non-smokers.

the non-smoker group, the protein levels of RIP2 and P-NF- $\kappa B$ and the ratio of P-NF- $\kappa B$ to total NF- $\kappa$ B were markedly increased in the smoker group (Fig. 1).

Representative immunohistochemical stainings of NOD1, RIP2, NF- $\kappa B$ and P-NF- $\kappa B$ in oral mucosa of non-smokers and smokers were shown in Figure 2. Immunohistochemical assays revealed strong staining intensity of NOD1 and NF- $\mathrm{\kappa B}$ in oral mucosal epithelium of non-smokers, whereas strong staining intensity of RIP2 and P-NF- $\kappa B$ was noted in oral 


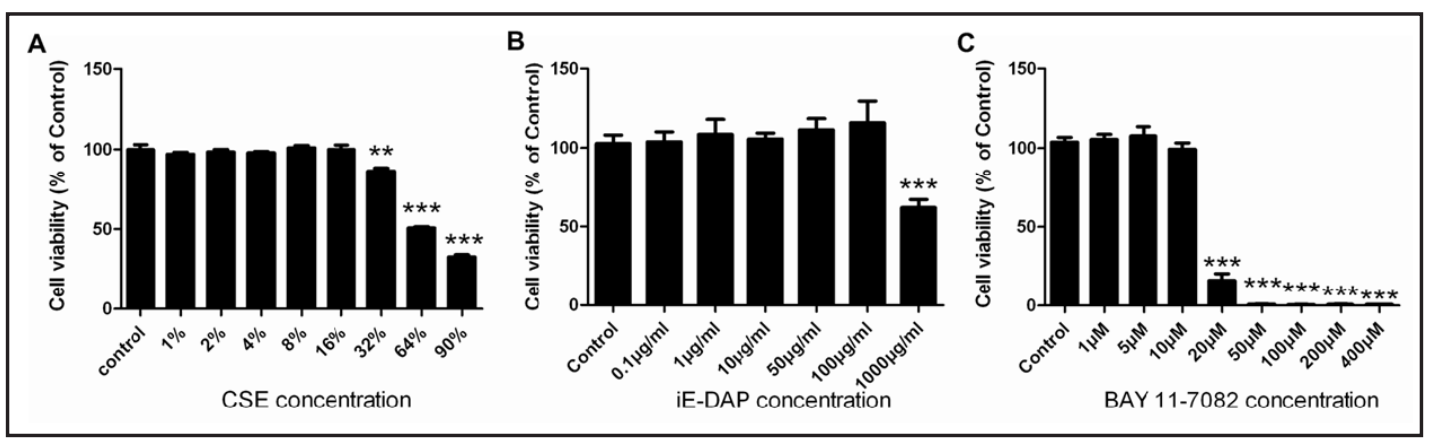

Fig. 3. Effects of different concentrations of CSE, iE-DAP, and BAY 11-7082 on the viability of Leuk-1 cells. Treatment of Leuk-1 cells with $1 \%, 2 \%$ or $4 \%$ CSE for 24 h did not significantly decrease the cell viability (A). Treatment of Leuk-1 cells with $50 \mu \mathrm{g} / \mathrm{ml}$ iE-DAP for $24 \mathrm{~h}$ did not markedly alter the cell viability (B). Treatment of Leuk-1 cells with $10 \mu \mathrm{M}$ BAY 11-7082 for $24 \mathrm{~h}$ did not clearly reduce the cell viability (C). Relative cell viability was represented as means \pm SE $(\mathrm{n}=4)$. Statistical significance: ${ }^{* *} P<0.01,{ }^{* * *} P<0.001$, vs. control.

Fig. 4. The time-course alteration of NOD1 expression in Leuk-1 cells exposed to CSE. Representative immunoblot bands of NOD1 (A). Density analyses of bands indicated that 4\% CSE exposure significantly reduced NOD1 expression in Leuk-1 cells at $12 \mathrm{~h}$ and $24 \mathrm{~h}$, especially at $24 \mathrm{~h}$ (B). Density data of bands were represented as means \pm SE $(\mathrm{n}=3)$. Statistical significance: ${ }^{* *} P<0.01$, vs. control.

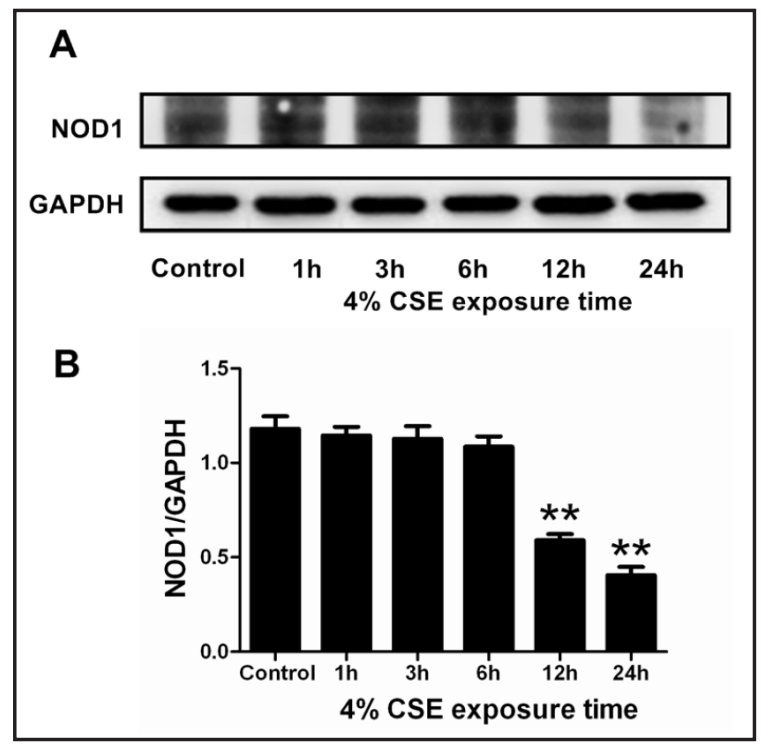

mucosa epithelium of smokers. Digital image analysis results indicated that the expression of NOD1 and NF- $\kappa$ B in oral mucosal epithelium of the smoker group significantly decreased than that of the non-smoker group, while the expression of RIP2 and P-NF- $\mathrm{kB}$ in oral mucosal epithelium of the smoker group significantly increased than that of the non-smoker group (Fig. 2).

$h B D-1$ and -3 levels were decreased and hBD-2 level was increased in oral mucosa of smokers

Representative immunohistochemical results of hBD-1, -2, -3 in oral mucosa of nonsmokers and smokers were presented in Figure 2. Strong staining intensity of hBD-1 and hBD-3 was observed in oral mucosal epithelium of non-smokers, whereas weak or no staining intensity of hBD-1 and hBD-3 was noted in oral mucosal epithelium of smokers. Weak staining intensity of hBD-2 was found in oral mucosal epithelium of non-smokers, while strong staining intensity of hBD-2 was noted in oral mucosal epithelium of smokers. Digital image analysis results indicated that the expression of hBD-1 and hBD-3 in oral mucosal epithelium of the smoker group significantly reduced than that of the non-smoker group, while the expression of hBD-2 in oral mucosal epithelium of the smoker group remarkably increased than that of non-smoker group (Fig. 2). 
Fig. 5. CSE modulated expression levels of NOD1, RIP2, NF-KB and p-NF- $\mathrm{kB}$ in Leuk-1 cells. Immunoblot bands showed effects of CSE on expression levels of NOD1, RIP2, NF-kB, and p-NF- $\mathrm{kB}(\mathrm{A})$. Density analyses of immunoblot bands revealed that CSE treatment significantly down-regulated NOD1 level (B), up-regulated RIP2 level (C), suppressed NF- $\mathrm{KB}$ expression (D) and induced P-NF-KB expression (E) in Leuk-1 cells in a concentration-dependent manner. Density data of bands were represented as means \pm SE $(\mathrm{n}=3)$. Statistical significance: ${ }^{*} P<0.05$, ${ }^{*} P<0.01,{ }^{* * *} P<0.001$, vs. cells without CSE treatment.

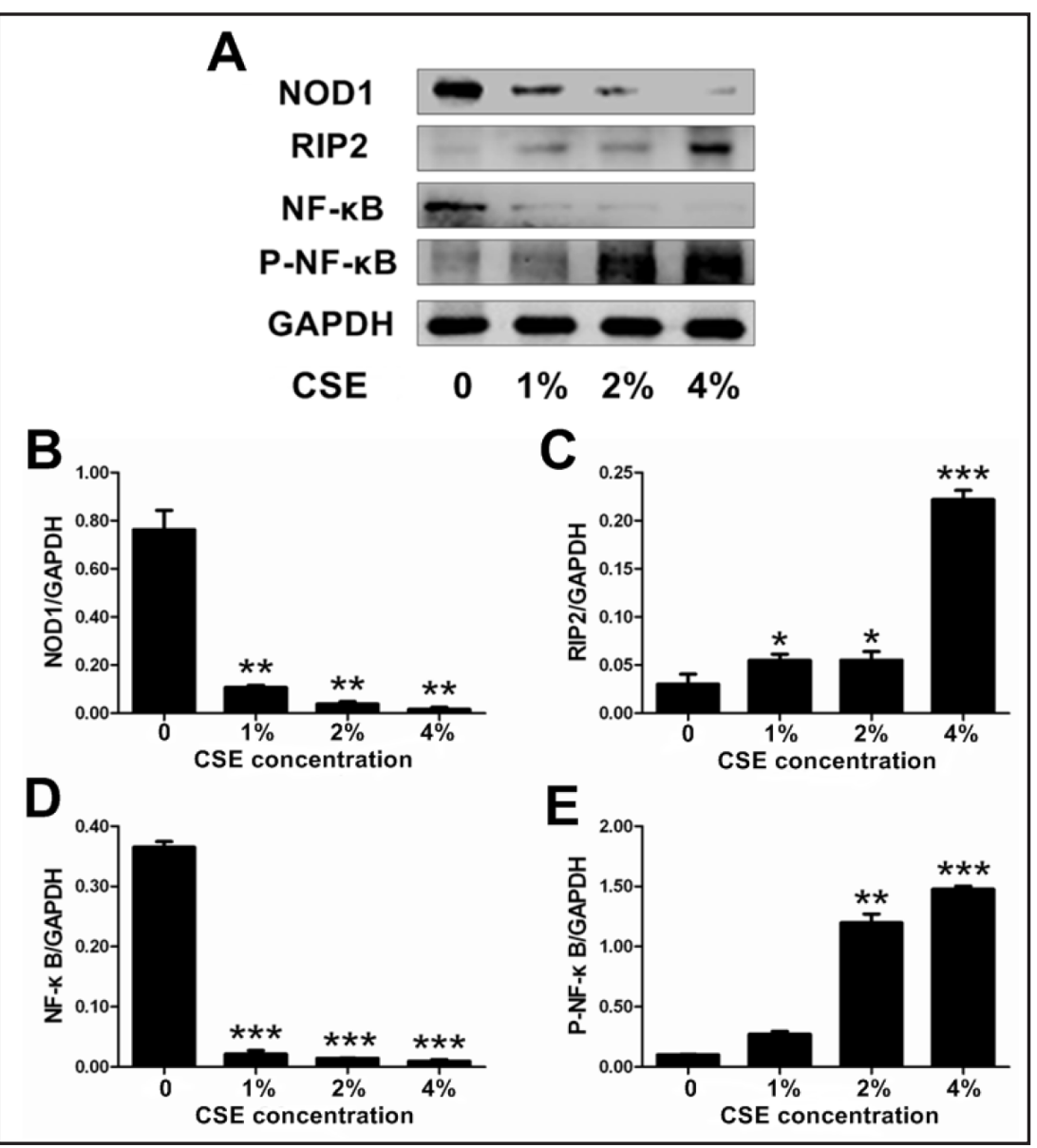

Effects of CSE, iE-DAP, and BAY 11-7082 on cell viability

MTT measurement was used to assess the effects of different concentrations of CSE, iE-DAP (NOD1 specific agonist), and BAY 11-7082 (NF- $\kappa B$ specific inhibitor) on the viability of Leuk-1 cells. As Figure 3A shown, 1\%, 2\%, 4\% CSE treatment for $24 \mathrm{~h}$ did not significantly decrease the cell viability. As Figure 3B shown, the treatment of $50 \mu \mathrm{g} / \mathrm{ml}$ iE-DAP for $24 \mathrm{~h}$ did not markedly alter the cell viability. As Figure 3C shown, the treatment of $10 \mu \mathrm{M}$ BAY 117082 for $24 \mathrm{~h}$ did not clearly reduce the cell viability.

CSE modulated the levels of crucial molecules of NOD1 signal pathway in Leuk-1 cells.

To better study the effect of cigarette smoke exposure on NOD1 signal pathway in oral mucosal epithelial cells, the expression of crucial components in NOD1 signal pathway was evaluated following CSE treatment. Our results of time-course experiment indicated that $4 \%$ CSE exposure significantly reduced NOD1 expression in Leuk-1 cells at $12 \mathrm{~h}$ and $24 \mathrm{~h}$, especially at 24h (Fig. 4). Cultured Leuk-1 cells were exposed to 1\%, 2\%, 4\% CSE or fresh medium (control) for $24 \mathrm{~h}$. Western blotting results indicated that CSE inhibited NOD1 and $\mathrm{NF}-\kappa \mathrm{B}$ protein expression in a concentration dependent manner. To the contrary, CSE induced RIP2 and P-NF- $\kappa B$ protein expression in a concentration dependent manner (Fig. 5).

Consistent with Western blotting results, immunofluorescence and confocal microscopy assays revealed that the expression of NOD1 clearly reduced and NF- $\mathrm{BB}$ p65 subunit translocated into nuclei in Leuk-1 cells following 4\% CSE treatment. Contrarily, the expression of RIP2 and P-NF- $\mathrm{KB}$ markedly enhanced in 4\% CSE treatment group compared with the control group (Fig. 6A, 6B, 6C, and 6D). 

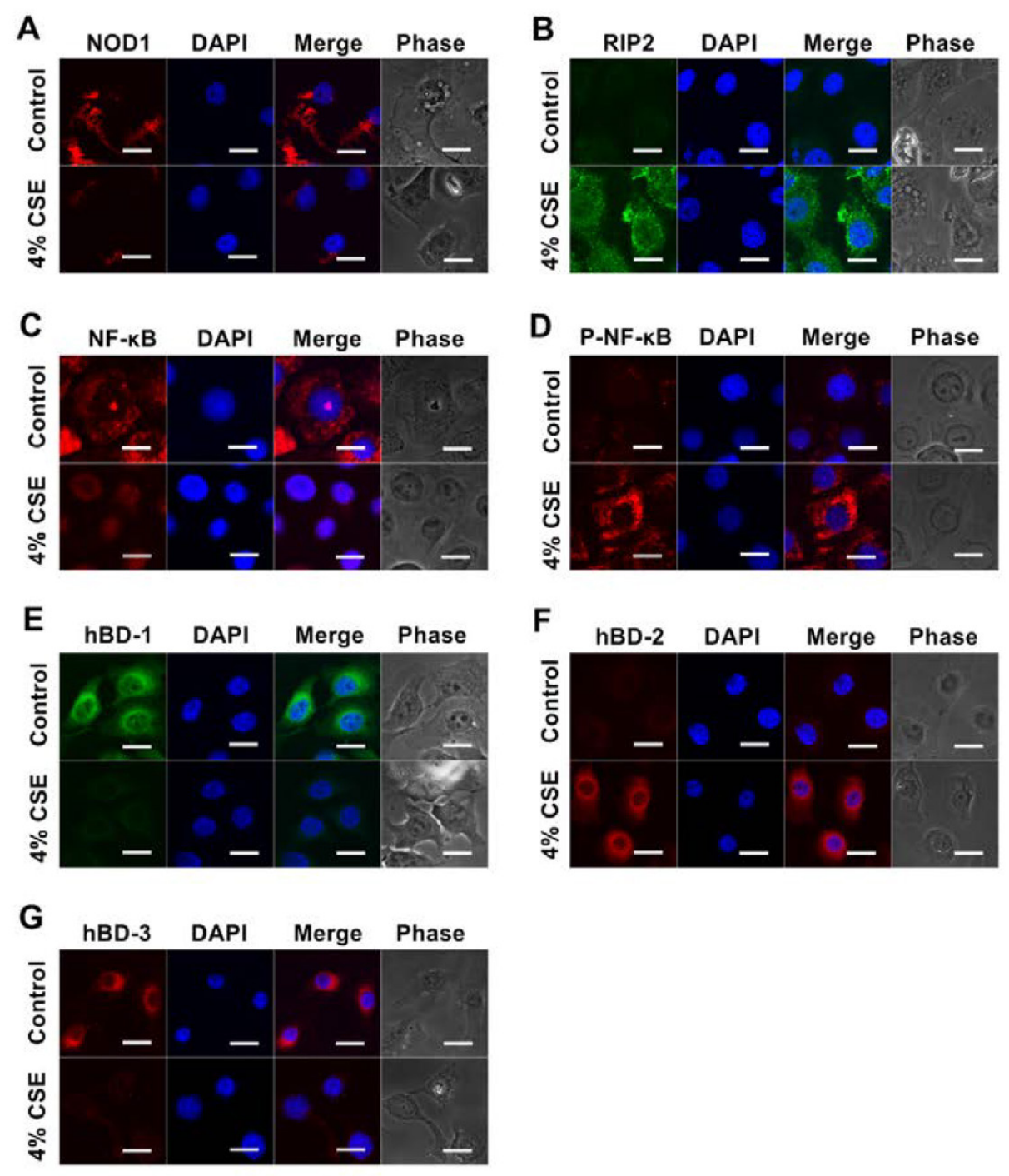

Fig. 6. CSE altered NOD1, RIP2, NF- $\mathrm{B}, \mathrm{p}-\mathrm{NF}-\kappa \mathrm{B}$ and hBDs protein expression levels in Leuk-1 cells. Immunofluorescence was observed by confocal microscopy. Following 4\% CSE treatment for 24h, NOD1 expression markedly reduced (A), RIP2 expression remarkably increased (B), NF- $\kappa$ B clearly translocated into nuclei (C) and P-NF- $\kappa$ B expression was notably activated in Leuk-1 cells (D). hBD-1 protein expression dramatically attenuated (E), hBD-2 protein expression clearly enhanced (F), and hBD-3 protein expression remarkably decreased $(G)$ in Leuk-1 cells following 4\% CSE treatment for $24 \mathrm{~h}$. Scale bar $=20 \mu \mathrm{m}$.

CSE regulated the expression and secretion of hBD-1, -2 and -3 by Leuk-1 cells.

We next examined effects of CSE on hBDs expression in vitro. Because of their extremely small size (about 4 7 kD), immunoblotting of hBDs remains a challenge. Thus, the immunofluorescence, qRT-PCR and ELISA were preformed in the present study. Immunofluorescence results indicated 4\% CSE treatment suppressed hBD-1 and hBD-3 protein expression. However, 4\% CSE treatment activated the expression of hBD-2 in leuk-1 cells (Fig. 6E, 6F, and 6G).

To illustrate whether regulatory effects of CSE on hBDs expression occurred at transcriptional and secretory levels, qRT-PCR and ELISA were performed to determine mRNA levels of hBDs in Leuk- 1 cells and protein levels of hBDs in the supernatant. There was a significant down-regulation of hBD-1 and hBD-3 levels following 4\% CSE exposure for 


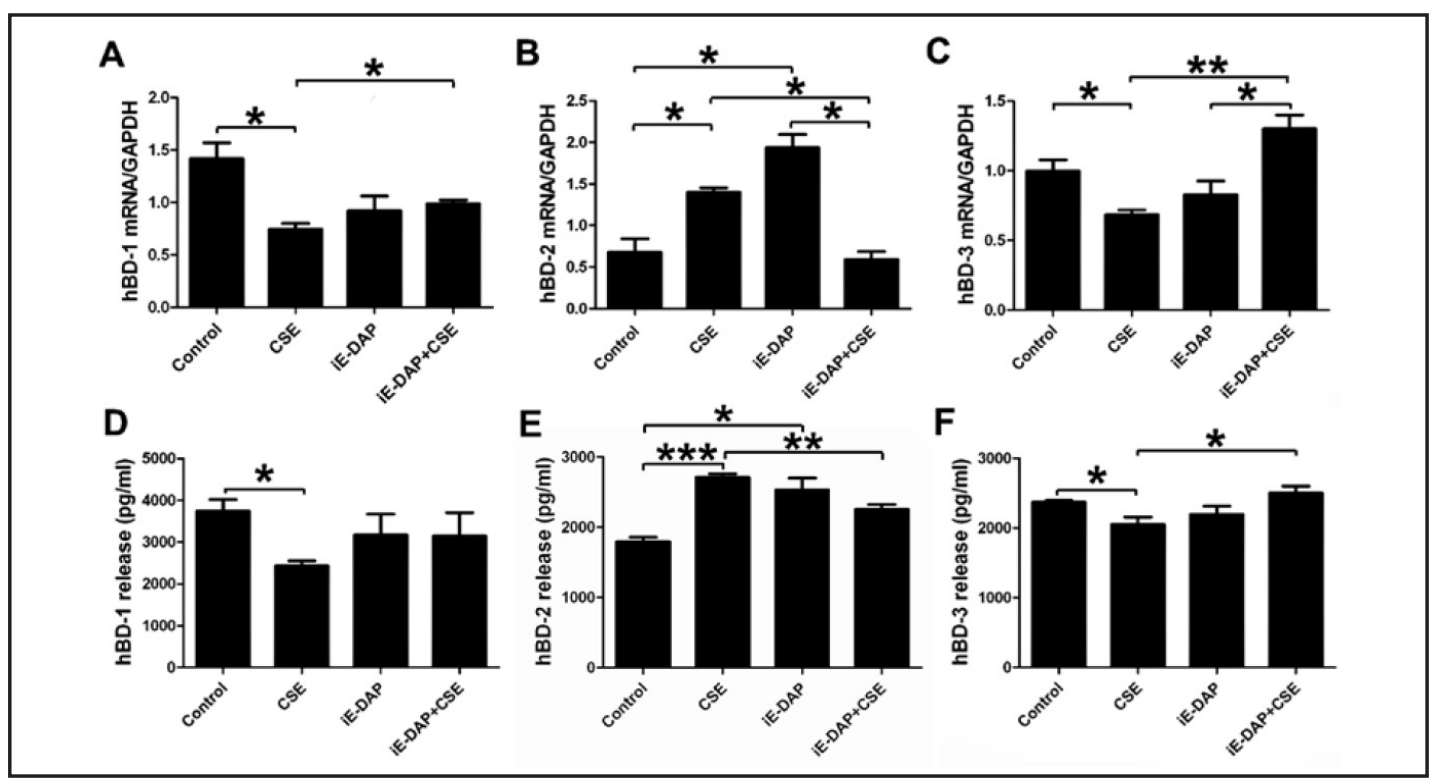

Fig. 7. iE-DAP treatment reversed the effects of CSE on hBD-1, -2, and -3 levels. Treatment of Leuk-1 cells with iE-DAP significantly abrogated the inhibition of CSE on hBD-1 mRNA expression (A). iE-DAP treatment significantly reversed the induction of CSE on hBD-2 mRNA level and the inhibition of CSE on hBD-3 mRNA level $(B, C)$. Treatment of Leuk-1 cells with iE-DAP significantly abrogated the suppression of CSE on hBD-1, -3 release and abolished the induction of CSE on hBD-2 release (D, E, F). The mRNA and ELISA data were represented as means $\pm \mathrm{SE}(\mathrm{n}=3)$. Statistical significance: ${ }^{*} P<0.05,{ }^{* *} P<0.01,{ }^{* * *} P<0.001$.

24h. However, 4\% CSE treatment remarkably up-regulated hBD-2 level (Fig. 7 and Fig. 8). These results suggested that CSE attenuated hBD-1 and hBD-3 expression and augmented hBD-2 expression at mRNA and protein levels.

$i E-D A P$ treatment reversed the effects of CSE on $h B D-1,-2$, and -3 levels

To clarify the effect of iE-DAP on CSE-induced alteration of hBD-1, -2, -3 levels, Leuk1 cells were treated with iE-DAP and CSE, either alone or in combination with each other. Our data suggested that treatment of Leuk- 1 cells with iE-DAP significantly abrogated the inhibitory effect of CSE on hBD-1 mRNA level (Fig. 7A). iE-DAP treatment clearly reversed the induced effect of CSE on hBD-2 mRNA level and the inhibitory effect of CSE on hBD-3 mRNA level (Fig. 7B and 7C). iE-DAP treatment markedly removed the inhibitory effect of CSE on hBD-1, -3 releases and abolished the induced effect of CSE on hBD-2 release (Fig. 7D, 7E and 7F). Our results also indicated that iE-DAP treatment conspicuously enhanced the gene expression and release of hBD-2 by Leuk-1 cells (Fig. 7B and 7E).

\section{BAY 11-7082 treatment reversed the effects of CSE on $h B D-1,-2,-3$ levels}

To determine the effect of BAY 11-7082 (NF- $\kappa B$ specific inhibitor) on CSE-induced alteration of hBD-1, -2, -3 levels, Leuk-1 cells were treated with BAY 11-7082 and CSE, either alone or in combination with each other. Our results indicated that BAY 11-7082 treatment significantly abrogated the inhibitory effect of CSE on hBD-1 mRNA level (Fig. 8A). BAY 117082 treatment remarkably reversed the induced effect of CSE on hBD-2 mRNA level, while BAY 11-7082 treatment clearly removed the inhibitory effect of CSE on hBD-3 mRNA level (Fig. 8B and 8C). BAY 11-7082 treatment markedly abrogated the inhibitory effect of CSE on hBD-1, -3 releases and abolished the induced effect of CSE on hBD-2 release (Fig. 8D, $8 \mathrm{E}$, and $8 \mathrm{~F}$ ). Our data suggested BAY 11-7082 treatment prominently suppressed the gene expression of hBD-2 in Leuk-1 cells (Fig. 8B). The gene expression and release of hBD-3 were also inhibited by BAY 11-7082 treatment (Fig. 8C and 8F). 


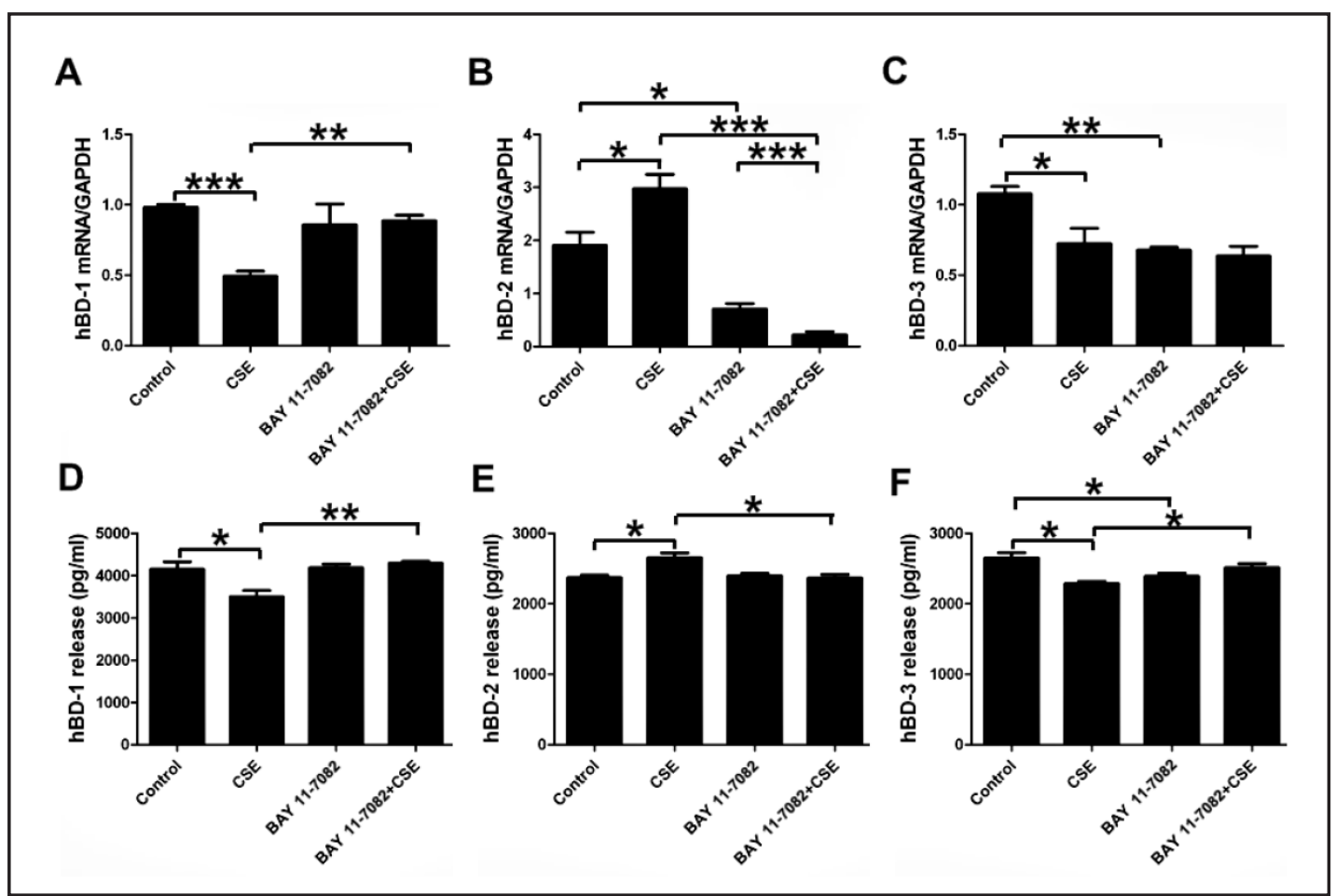

Fig. 8. BAY 11-7082 treatment reversed the effects of CSE on hBD-1, -2, and -3 levels. BAY 11-7082 treatment significantly abrogated the inhibitory effect of CSE on hBD-1 mRNA expression (A). BAY 11-7082 treatment remarkably reversed the induced effect of CSE on hBD-2 mRNA level (B), while the BAY 11-7082 treatment clearly removed the inhibitory effect of CSE on hBD-3 mRNA level (C). BAY 11-7082 treatment markedly abrogated the inhibitory effect of CSE on hBD-1, -3 releases and abolished the induced effect of CSE on hBD-2 release (D, E, F). The mRNA and ELISA data were represented as means $\pm S E(n=3)$. Statistical significance: ${ }^{*} P<0.05,{ }^{* *} P<0.01,{ }^{* * *} P<0.001$.

\section{Discussion}

Tobacco smoke contains 3,800 chemicals, including carbon monoxide, hydrogen cyanide, reactive oxidizing radicals, nicotine, aromatic hydrocarbons, aldehyde, heavy metals, phenolics and many carcinogens [26]. Long-term cigarette smoking is a major risk factor for respiratory and cardiovascular diseases, and is also known to adversely affect other organs [27]. Short- and long-term cigarette smoke exposure may have consequences associated with drug metabolism/detoxification, oxidative stress, inflammatory responses and mitochondrial dysfunction in tissues [27-29]. Smoking is believed to suppress the activation of innate immune system in response to bacterial infection. It has been elaborated that deficient functions of innate immune system seem to be of importance in smokingrelated diseases [30]. Smoking is a well-known contributing factor for precancerous and cancerous oral lesions. The percentage of inflammation and Candida of oral mucosa in smokers and waterpipe users is significantly higher than that in normal individuals [31]. Smoking habit has a direct impact on the course of disease of oral lichen planus and leukoplakia [32, 33]. Oral mucosal epithelium is the first tissue that encounters diverse toxic substances in cigarette smoke, so it is essential to study the influences of cigarette smoke on innate immune response of oral mucosa. An increasing body of data supports the critical role of NOD1 in oral innate immune responses [4,34]. Therefore, we investigated effects of cigarette smoke on NOD1 signal pathway and hBDs expression in oral mucosa.

An early study indicated that cigarette smoke extract (CSE) delayed NOD2 expression and affected NOD2/RIP2 interactions in intestinal epithelial cells [12]. It remains unknown

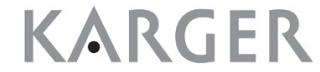




\section{Cellular Physiology Cell Physiol Biochem 2015;36:457-473 \begin{tabular}{ll|l} 
and Bioch 10.1159/000430112 & $\begin{array}{l}\text { O 2015 S. Karger AG, Basel } \\
\text { www.karger.com/cpb }\end{array}$ \\
\hline
\end{tabular} \\ Qian et al.: Smoking Modulates NOD1 Signaling}

whether NOD1 expression in oral mucosal epithelium is differential between smokers and non-smokers. In the present study, our results confirmed that NOD1 protein expression was down-regulated in oral mucosa of smokers. Moreover experimental results of Leuk-1 cells also supported that CSE inhibited NOD1 expression in a concentration-dependent manner. NOD1 stimulation reversed the regulatory effects of CSE on levels of hBD-1, -2 and -3 in the present study. Our recent study indicated that decreased NOD1 expression is significantly associated with oral squamous cell carcinoma (OSCC) progression [35]. These evidences could potentially link suppressive effects of smoking on NOD1 expression to smoking-related oral mucosal diseases.

In the present study, results indicated that RIP2 expression enhanced in oral mucosa of smokers. Study data of Leuk cells also confirmed that CSE augmented RIP2 expression. A recent study suggested that RIP1 expression remarkably increased in cigarette smokeexposed mouse lung and was significantly induced by CSE in human bronchial epithelial cells [36]. As members of receptor-interacting protein family, RIP1 and RIP2 share many common functions in cell death and cell stress signaling [37]. However, as a dual functional molecule, RIP2 also plays a crucial role in innate immune and inflammation response. Beyond the adaptor in NOD1/NF- $\mathrm{kB}$ signal pathway, RIP2 seemed to play more complicated roles in epithelial cells exposed to cigarette smoke. Further studies should be preformed to clarify the role of RIP2 in cigarette smoke-related molecular signaling. It has been confirmed that cigarette smoke or CSE exposure could activate NF- $\kappa B$ phosphorylation and induce proinflammatory effects in aerodigestive cells $[38,39]$. Coincidentally, the present study indicated that cigarette smoke or CSE exposure up-regulated P-NF- $\kappa \mathrm{B}$ expression in oral mucosa epithelium and Leuk-1 cells. NF- $\mathrm{KB}$ is considered a critical factor in response to cigarette smoke exposure. The stimulation of CSE or some ingredients of cigarette smoke could result in nuclear translocation of NF- $\kappa \mathrm{B}$, which could modulate the transcriptive activity of downstream cytokines and antimicrobial peptides [40-42]. It has been reported that cigarette smoke inhibited NF- $\mathrm{KB}$ activation and suppressed innate immune responses to pathogenic microbes in airway epithelial cells $[43,44]$. An early study revealed that CSE inhibited NF- $\kappa B$ activation and the consequent expression of defense genes in airway epithelial cells in response to $H$. influenzae. This decreased activation of NF- $\kappa B$ was not attributable to cell loss or cytotoxicity [45]. Our results suggested that NF- $\mathrm{BB}$ inhibitor treatment reversed regulatory effects of CSE on hBDs levels. As a result, existed data and the present results indicated that NF- $\mathrm{KB}$ could play a crucial role in innate immune and tissue homeostasis.

Study data about effects of smoking on hBD-1 and - 3 levels are very little in the literature. Wolgin et al. found that the expression of hBD-1 mRNA was significantly reduced in gingival samples of smokers compared to that of non-smokers [13]. An early study indicated that mouse $\beta$ defensin (mBD)-1 expression decreased in the lungs of cigarette smoke-exposed mice compared with air-exposed mice [46]. Our results suggested that cigarette smoke or CSE exposure inhibited hBD-1 and hBD-3 levels in oral mucosal epithelial cells. This could be related to smoking-related local defense suppression.

Although many studies focused on effects of smoking on hBD-2 expression in the literature, study data are in conflict. It was found that the expression of hBD-2 mRNA was significantly reduced in gingival samples of smokers compared to that of non-smokers [13]. Another study suggested that the pre-treatment with nicotine reduced a stimulating effect of TNF- $\alpha$ on the gene expression of hBD-2 in HaCaT keratinocytes [47]. It was found that hBD2 protein level in gingival crevicular fluid was significantly higher in smoker patients with gingivitis than that of non-smoker patients with gingivitis, while hBD-2 level in the gingival crevicular fluid was significantly higher in smoker patients with generalized aggressive periodontitis than that of non-smoker patients with generalized aggressive periodontitis [48]. It was reported that whole cigarette smoke exposure up-regulated hBD-2 and hBD-3 


\section{Cellular Physiology Cell Physiol Biochem 2015;36:457-473 \\ \begin{tabular}{l|l|l} 
DOI: 10.1159/000430112 & (C) 2015 S. Karger AG, Basel
\end{tabular} \\ \begin{tabular}{l|l} 
and Biochemistry Published online: May 11, 2015 & www.karger.com/cpb \\
\cline { 1 - 2 }
\end{tabular} \\ Qian et al.: Smoking Modulates NOD1 Signaling}

levels by human gingival epithelial cells [10]. It was observed that CSE modulated hBD-2 mRNA level in human gingival epithelial cells [11]. These differential results in the literature could be explained with different patterns and time of cigarette smoke exposure, tissue type, and gene or protein expression level, etc. Our present results indicated that cigarette smoke or CSE exposure augmented hBD-2 level in oral mucosal epithelial cells. The induction of hBD-2 following cigarette exposure could be due to proinflammatory response of cells [10].

In the present study, the difference of altered extent of hBDs levels was observed between the mRNA level in Leuk-1 cells and the secretory level in supernatant of cell culture. The altered extent of hBDs at secretory level was more minor than that at expression level. Firstly, this difference may be resulted from the regulation of antimicrobial peptide expression at transcriptional, post-transcriptional and post-translational levels [49]. Secondly, this difference may be explained that only a part of intracellular hBDs could be released into supernatant of cell culture. In the post-translational translocation process, the synthesis and translocation of the preproteins are not coupled [50].

hBDs are critical effectors of host defense, which play a vital role in innate defense of aerodigestive epithelium and control many commensal and pathogenic bacteria. hBD-1 is inherently expressed in epithelial cells and may be up-regulated by bacterial products. hBD-2 is inductively expressed in epithelial cells and could be strongly up-regulated by both pathogenic bacteria and proinflammatory cytokines. hBD3 is expressed in normal epithelium and may be up-regulated by bacteria, IFN- $\gamma$ and growth factors [51]. Although NOD1 stimulation did not altered significantly levels of hBD-1 and -3 in the present study, NOD1 stimulation abrogated or reversed the suppressive effects of CSE on levels of hBD-1 and -3. Likewise, NF- $\kappa B$ inhibitor treatment had no remarkable effects on hBD-1 level, which is consistent with a recent report [52]. NF- $\kappa B$ inhibitor treatment still reversed the inhibitory effect of CSE on hBD-1 level. Our results indicated that NOD1 stimulation conspicuously enhanced hBD-2 level, which is in accordance with an early study [3]. NF- $\kappa B$ inhibitor treatment prominently suppressed the levels of hBD-2 and hBD-3, which is consistent with a previous study [52]. In short, our data revealed that NOD1 stimulation or NF- $\kappa B$ inhibitor treatment reversed the effects of CSE on hBD-1, -2 , and -3 levels. These results indicated that NOD1 signal pathway played an important part in the regulatory effects of CSE on hBDs levels in oral mucosal epithelial cells. hBDs play critical roles in antitumor, antimicrobial activity, homeostasis maintenance, wound healing, and immunomodulatory effect. The regulatory effects of CSE on hBDs levels could be one of important aspects on smoking-related innate immune dysfunction and oral mucosal diseases occurrence.

\section{Conclusions}

The present study indicated that cigarette smoke could potentially modulate the expression of crucial molecules of NOD1 signal pathway and hBDs in human oral mucosal epithelium. NOD1 signal pathway could play an important role in the regulatory effects of CSE on hBDs levels in oral mucosal epithelial cells.

\section{Acknowledgment}

This work was supported by the National Natural Scientific Foundation of China (No.81070839 \& No.81273121), Jiangsu Province's Outstanding Medical Academic Leader program (No.LJ201110), the Key Project of Science and Technology Department of Jiangsu Province (No. BL2014018), and the Science and Technology Development Program of Nanjing (No.201402033).

We would like to thank Professor Li Mao (School of Dentistry, University of Maryland, USA) for his kind provision of oral mucosal epithelial (Leuk-1) cell line. We also would like to 


\section{Cellular Physiology Cell Physiol Biochem 2015;36:457-473 \begin{tabular}{l|l} 
DOI: 10.1159/000430112 & (C) 2015 S. Karger AG, Basel
\end{tabular} \\ Qian et al.: Smoking Modulates NOD1 Signaling}

thank Professor Wantao Chen (Department of Oral and Maxillofacial Surgery, Ninth People's Hospital, School of Stomatology, Shanghai Jiao Tong University School of Medicine, China) for his kind help to our experiment.

\section{Disclosure Statement}

The authors declare no conflicts of interest.

\section{References}

1 Lee J, Taneja V, Vassallo R: Cigarette smoking and inflammation: Cellular and molecular mechanisms. J Dent Res 2012;91:142-149.

2 Feldman C, Anderson R: Cigarette smoking and mechanisms of susceptibility to infections of the respiratory tract and other organ systems. J Infect 2013;67:169-184.

3 Uehara A, Fujimoto Y, Fukase K, Takada H: Various human epithelial cells express functional Toll-like receptors, NOD1 and NOD2 to produce anti-microbial peptides, but not proinflammatory cytokines. Mol Immunol 2007;44:3100-3111.

4 Uehara A, Takada H: Synergism between TLRs and NOD1/2 in oral epithelial cells. J Dent Res 2008;87:682686.

5 Sugawara Y, Uehara A, Fujimoto Y, Kusumoto S, Fukase K, Shibata K, Sugawara S, Sasano T, Takada H: Tolllike receptors, NOD1, and NOD2 in oral epithelial cells. J Dent Res 2006;85:524-529.

6 Inohara N, Koseki T, Lin J, del Peso L, Lucas PC, Chen FF, Ogura Y, Nunez G: An induced proximity model for NF-kappa B activation in the Nod1/RIPK and RIP signaling pathways. J Biol Chem 2000;275:27823-27831.

7 Hasegawa M, Fujimoto Y, Lucas PC, Nakano H, Fukase K, Nunez G, Inohara N: A critical role of RICK/RIP2 polyubiquitination in NOD-induced NF- $\kappa$ B activation. EMBO J 2008;27:373-383.

8 Park JH, Kim YG, Shaw M, Kanneganti TD, Fujimoto Y, Fukase K, Inohara N, Nunez G: Nod1/RICK and TLR signaling regulate chemokine and antimicrobial innate immune responses in mesothelial cells. J Immunol 2007;179:514-521.

9 Zasloff M: Innate immunity, antimicrobial peptides, and protection of the oral cavity. Lancet 2002;360:1116-1117.

10 Semlali A, Witoled C, Alanazi M, Rouabhia M: Whole cigarette smoke increased the expression of TLRs, HBDs, and proinflammory cytokines by human gingival epithelial cells through different signaling pathways. PLoS One 2012;7:e52614.

11 Mahanonda R, Sa-Ard-Iam N, Eksomtramate M, Rerkyen P, Phairat B, Schaecher KE, Fukuda MM, Pichyangkul S: Cigarette smoke extract modulates human beta-defensin-2 and interleukin-8 expression in human gingival epithelial cells. J Periodontal Res 2009;44:557-564.

12 Aldhous MC, Soo K, Stark LA, Ulanicka AA, Easterbrook JE, Dunlop MG, Satsangi J: Cigarette smoke extract (CSE) delays NOD2 expression and affects NOD2/RIPK2 interactions in intestinal epithelial cells. PLoS One 2011;6:e24715.

13 Wolgin M, Liodakis S, Ulrich I, Zakrzewicz A, Kielbassa AM, Pries AR: Gene expression of human beta defensins- 1 and -2 is significantly reduced in non-inflamed keratinized oral tissue of smokers. J Dent 2012;40:949-954.

14 Arcolia V, Paci P, Dhont L, Chantrain G, Sirtaine N, Decaestecker C, Remmelink M, Belayew A, Saussez S: Helicase-like transcription factor: A new marker of well-differentiated thyroid cancers. BMC Cancer 2014;14:492.

15 Sarioglu S, Unlu M, Sakar M, Camsari T, Turkmen M, Ellidokuz H: Quantification of immune deposits in renal diseases. Appl Immunohistochem Mol Morphol 2011;19:470-477.

16 Jiang Y, Dai A, Zhou Y, Peng G, Hu G, Li B, Sham JS, Ran P: Nicotine elevated intracellular $\mathrm{Ca}^{2+}$ in rat airway smooth muscle cells via activating and up-regulating $\alpha 7$-nicotinic acetylcholine receptor. Cell Physiol Biochem 2014;33:389-401.

17 Gould NS, Min E, Gauthier S, Martin RJ, Day BJ: Lung glutathione adaptive responses to cigarette smoke exposure. Respir Res 2011;12:133. 


\section{Cellular Physiology Cell Physiol Biochem 2015;36:457-473 \begin{tabular}{l|l} 
DOI: 10.1159/000430112 & (C) 2015 S. Karger AG, Basel
\end{tabular} \begin{tabular}{l|l|} 
and Biochemistry Published online: May 11, 2015 & www.karger.com/cpb \\
\cline { 1 - 2 }
\end{tabular} \\ Qian et al.: Smoking Modulates NOD1 Signaling}

18 Di Cello F, Flowers VL, Li H, Vecchio-Pagan B, Gordon B, Harbom K, Shin J, Beaty R, Wang W, Brayton C, Baylin SB, Zahnow CA: Cigarette smoke induces epithelial to mesenchymal transition and increases the metastatic ability of breast cancer cells. Mol cancer 2013;12:90.

19 Kastamoulas M, Chondrogiannis G, Kanavaros P, Vartholomatos G, Bai M, Briasoulis E, Arvanitis D, Galani V: Cytokine effects on cell survival and death of A549 lung carcinoma cells. Cytokine 2013;61:816-825.

20 Hoang M, Potter JA, Gysler SM, Han CS, Guller S, Norwitz ER, Abrahams VM: Human fetal membranes generate distinct cytokine profiles in response to bacterial Toll-like receptor and NOD-like receptor agonists. Biol Reprod 2014;90:39.

21 Wong CK, Hu S, Leung KM, Dong J, He L, Chu YJ, Chu IM, Qiu HN, Liu KY, Lam CW: NOD-like receptors mediated activation of eosinophils interacting with bronchial epithelial cells: A link between innate immunity and allergic asthma. Cell Mol Immunol 2013;10:317-329.

22 Chondrogiannis G, Kastamoulas M, Kanavaros P, Vartholomatos G, Bai M, Baltogiannis D, Sofikitis N, Arvanitis D, Galani V: Cytokine effects on cell viability and death of prostate carcinoma cells. Biomed Res Int 2014;2014:536049.

23 Krishnan N, Bencze G, Cohen P, Tonks NK: The anti-inflammatory compound BAY-11-7082 is a potent inhibitor of protein tyrosine phosphatases. FEBS J 2013;280:2830-2841.

24 Bogefors J, Kvarnhammar AM, Hockerfelt U, Cardell LO: Reduced tonsillar expression of human betadefensin 1, 2 and 3 in allergic rhinitis. FEMS Immunol Med Microbiol 2012;65:431-438.

25 He P, Wang AG, Xia T, Gao P, Niu Q, Guo LJ, Xu BY, Chen XM: Mechanism of the neurotoxic effect of PBDE47 and interaction of PBDE-47 and PCB153 in enhancing toxicity in SH-SY5Y cells. Neurotoxicology 2009;30:10-15.

26 Gan G, Hu R, Dai A, Tan S, Ouyang Q Fu D, Jiang D: The role of endoplasmic reticulum stress in emphysema results from cigarette smoke exposure. Cell Physiol Biochem 2011;28:725-732.

27 Nemmar A, Raza H, Subramaniyan D, Yasin J, John A, Ali BH, Kazzam EE: Short-term systemic effects of nose-only cigarette smoke exposure in mice: Role of oxidative stress. Cell Physiol Biochem 2013;31:15-24.

28 Bazzini C, Rossetti V, Civello DA, Sassone F, Vezzoli V, Persani L, Tiberio L, Lanata L, Bagnasco M, Paulmichl M, Meyer G, Garavaglia ML: Short- and long- term effects of cigarette smoke exposure on glutathione homeostasis in human bronchial epithelial cells. Cell Physiol Biochem 2013;32:129-145.

29 Raza H, John A, Nemmar A: Short-term effects of nose-only cigarette smoke exposure on glutathione redox homeostasis, cytochrome P450 1A1/2 and respiratory enzyme activities in mice tissues. Cell Physiol Biochem 2013;31:683-692.

30 Prieto A, Reyes E, Bernstein ED, Martinez B, Monserrat J, Izquierdo JL, Callol L, de LP, Alvarez-Sala R, Alvarez-Sala JL, Villarrubia VG, Alvarez-Mon M: Defective natural killer and phagocytic activities in chronic obstructive pulmonary disease are restored by glycophosphopeptical (inmunoferon). Am J Respir Crit Care Med 2001;163:1578-1583.

31 Seifi S, Feizi F, Mehdizadeh M, Khafri S, Ahmadi B: Evaluation of cytological alterations of oral mucosa in smokers and waterpipe users. Cell J 2014;15:302-309.

32 Klosek SK, Sporny S, Stasikowska-Kanicka O, Kurnatowska AJ: Cigarette smoking induces overexpression of c-Met receptor in microvessels of oral lichen planus. Arch Med Sci 2011;7:706-712.

33 Dietrich T, Reichart PA, Scheifele C: Clinical risk factors of oral leukoplakia in a representative sample of the us population. Oral oncol 2004;40:158-163.

34 Curtis M: The oral commensal microbiota bites back through NOD1. Cell host \& microbe 2013;13:503-505.

35 Wang X, Jiang W, Duan N, Qian Y, Zhou Q, Ye P, Jiang H, Bai Y, Zhang W, Wang W: NOD1, RIP2 and Caspase12 are potentially novel biomarkers for oral squamous cell carcinoma development and progression. Int J Clin Exp Pathol 2014;7:1677-1686.

36 Wang Q, Chen W, Xu X, Li B, He W, Padilla MT, Jang JH, Nyunoya T, Amin S, Wang X, Lin Y: RIP1 potentiates BPDE-induced transformation in human bronchial epithelial cells through catalase-mediated suppression of excessive reactive oxygen species. Carcinogenesis 2013;34:2119-2128.

37 Bertrand MJ, Lippens S, Staes A, Gilbert B, Roelandt R, De Medts J, Gevaert K, Declercq W, Vandenabeele P: cIAP1/2 are direct E3 ligases conjugating diverse types of ubiquitin chains to receptor interacting proteins kinases 1 to 4 (RIP1-4). PLoS One 2011;6:e22356.

38 Yang SR, Valvo S, Yao H, Kode A, Rajendrasozhan S, Edirisinghe I, Caito S, Adenuga D, Henry R, Fromm G, Maggirwar S, Li JD, Bulger M, Rahman I: IKK alpha causes chromatin modification on pro-inflammatory genes by cigarette smoke in mouse lung. Am J Respir Cell Mol Biol 2008;38:689-698. 


\section{Cellular Physiology Cell Physiol Biochem 2015;36:457-473 \begin{tabular}{c|c|c|}
\cline { 2 - 2 } DOI: 10.1159/000430112 & O 2015 S. Karger AG, Basel \\
and Biochemistry
\end{tabular} www.karger.com/cpb \\ Qian et al.: Smoking Modulates NOD1 Signaling}

39 Pera T, Atmaj C, van der Vegt M, Halayko AJ, Zaagsma J, Meurs H: Role for TAK1 in cigarette smoke-induced proinflammatory signaling and IL-8 release by human airway smooth muscle cells. Am J Physiol Lung Cell Mol Physiol 2012;303:L272-L278.

40 Chen Y, Wang H, Luo G, Dai X: SIRT4 inhibits cigarette smoke extracts-induced mononuclear cell adhesion to human pulmonary microvascular endothelial cells via regulating NF- $\mathrm{KB}$ activity. Toxicol Lett 2014;226:320-327.

41 Li Q Zhou XD, Kolosov VP, Perelman JM: Nicotine reduces TNF- $\alpha$ expression through a $\alpha 7 \mathrm{nAChR/MyD88/}$ NF-кB pathway in HBE16 airway epithelial cells. Cell Physiol Biochem 2011;27:605-612.

42 Wu L, Zhou Y, Zhou Z, Liu Y, Bai Y, Xing X, Wang X: Nicotine induces the production of IL-1 $\beta$ and IL-8 via the $\alpha 7 \mathrm{nAChR} / \mathrm{NF}-\kappa \mathrm{B}$ pathway in human periodontal ligament cells: An in vitro study. Cell Physiol Biochem 2014;34:423-431.

43 Kulkarni R, Rampersaud R, Aguilar JL, Randis TM, Kreindler JL, Ratner AJ: Cigarette smoke inhibits airway epithelial cell innate immune responses to bacteria. Infect Immun 2010;78:2146-2152.

44 Bauer CM, Dewitte-Orr SJ, Hornby KR, Zavitz CC, Lichty BD, Stampfli MR, Mossman KL: Cigarette smoke suppresses type I interferon-mediated antiviral immunity in lung fibroblast and epithelial cells. J Interferon Cytokine Res 2008;28:167-179.

45 Manzel LJ, Shi L, O’Shaughnessy PT, Thorne PS, Look DC: Inhibition by cigarette smoke of nuclear factor- $\kappa \mathrm{B}-$ dependent response to bacteria in the airway. Am J Respir Cell Mol Biol 2011;44:155-165.

46 Shibata Y, Abe S, Inoue S, Takabatake N, Igarashi A, Takeishi Y, Sata M, Kubota I: Altered expression of antimicrobial molecules in cigarette smoke-exposed emphysematous mice lungs. Respirology 2008;13:1061-1065.

47 Wolgin M, Liodakis S, Pries AR, Zakrzewicz A, Kielbassa AM: HBD-1 and HBD-2 expression in hacat keratinocytes stimulated with nicotine. Arch Oral Biol 2012;57:814-819.

48 Ertugrul AS, Sahin H, Dikilitas A, Alpaslan NZ, Bozoglan A, Tekin Y: Gingival crevicular fluid levels of human beta-defensin-2 and cathelicidin in smoker and non-smoker patients: A cross-sectional study. J Periodontal Res 2014;49:282-289.

49 Carpenter S, Ricci EP, Mercier BC, Moore MJ, Fitzgerald KA: Post-transcriptional regulation of gene expression in innate immunity. Nat Rev Immunol 2014;14:361-376.

50 Mulder KC, Bandola J, Schumann W: Construction of an artificial secYEG operon allowing high level secretion of $\alpha$-amylase. Protein Expr Purif 2013;89:92-96.

51 Kimball JR, Nittayananta W, Klausner M, Chung WO, Dale BA: Antimicrobial barrier of an in vitro oral epithelial model. Arch Oral Biol 2006;51:775-783.

52 Liu J, Du X, Chen J, Hu L, Chen L: The induction expression of human $\beta$-defensins in gingival epithelial cells and fibroblasts. Arch Oral Biol 2013;58:1415-1421. 